\title{
SISTEM PENDUKUNG KEPUTUSAN MEMILIH JURUSAN DI PERGURUAN TINGGI MENGGUNAKAN METODE ANALYTICAL HIERARCHY PROCESS (AHP)
}

\author{
Hendra Gunawan \\ Program Studi Sistem Informasi \\ STMIK Indonesia Mandiri, Jl.Jakarta No.79 Bandung \\ Email: hendra@stmik-im.ac.id
}

\begin{abstract}
ABSTRAK
Banyaknya perguruan tinggi swasta di Jawa Barat khususnya Kota Bandung dan sekitarnya yang membuka berbagai jurusan yang ditawarkan kepada masyarakat dengan berbagai informasi yang menarik, baik itu dari segi biaya maupun prospek setelah lulus dari perguruan tinggi tersebut. Hal tersebut membuat calon mahasiswa bingung mau memilih jurusan dan kampus mana yang cocok dan tepat.

Dari Permasalahan tersebut muncul sebuah gagasan untuk membangun sebuah sistem pendukung keputusan memilih jurusan yang dapat membantu calon mahasiswa dalam memilih jurusan di perguruan tinggi. Sistem ini menggunakan Metode AHP (Analytical Hierarchy Process) untuk membantu perhitungan pendukung keputusannya, serta menggunakan bahasa pemrograman PHP dan MySQL untuk implementasinya.

Hasil penelitian ini berupa Aplikasi Sistem Pendukung Keputusan Memilih Jurusan di Perguruan Tinggi dengan Metode Analytical Hierarchy Process (AHP) yang memudahkan bagian calon mahasiswa untuk memilih jurusan yang sesuai harapan.
\end{abstract}

Kata Kunci : Sistem Pendukung Keputusan, Analytical Hierarchy Process, Jurusan, perguruan tinggi

\section{PENDAHULUAN}

\subsection{Latar Belakang}

Pemilihan jurusan oleh seorang calon mahasiswa bukanlah hal yang mudah karena banyak hal yang harus dipertimbangkan seperti biaya, kemampuan diri, dan prospek lulusan perguruan tinggi yang dituju. Banyaknya jurusan yang diselenggarakan oleh Perguruan Tinggi bertujuan untuk menampung minat dan bakat dari calon mahasiswa yang akan melanjutkan pendidikan ke jenjang yang lebih tinggi. Akan tetapi tidak sedikit calon mahasiswa tersebut memilih jurusan kuliah asal pilih yang penting bisa kuliah tanpa mempertimbangkan kelanjutannya, baik dalam masa perkuliahan maupun pasca kelulusan. Hal ini menyebabkan rendahnya tingkat grade nilai yang dicapai oleh mahasiswa tersebut yang tentu saja menghambat kelulusan.

Berdasarkan penjelasan diatas, dibuatlah sebuah Sistem Pendukung Keputusan untuk membantu calon mahasiswa untuk memilih jurusan di perguruan tinggi, dengan 
mengambil judul "Sistem Pendukung Keputusan Memilih Jurusan di Perguruan Tinggi Menggunakan Metode Analytical Hierarchy Process (AHP) “.

\subsection{Tujuan}

Tujuan penelitian ini adalah sebagai berikut :

1. Bagaimana cara membuat Sistem Pendukung Keputusan untuk memilih jurusan di perguruan tinggi.

2. Menjelaskan faktor-faktor dan kriteria yang mempengaruhi proses pemilihan jurusan.

3. Untuk menerapkan metode Analytical Hierarchy Process (AHP) yang digunakan sebagai proses penentuan jurusan.

\section{LANDASAN TEORI}

\section{Metode Analytical Hierarchy Process (AHP)}

Analytic Hierarchy Process (AHP) telah diterima sebagai model pengambilan keputusan yang bersifat multikriteria, oleh orang-orang akademik maupun praktisi (Mauro, 2001). Kriteria-kriteria dibandingkan dalam bentuk perbandingan berpasangan, untuk membentuk suatu matriks preferensi, demikian pula halnya dengan alternatifalternatif. Salah satu kehandalan AHP adalah dapat melakukan analisis secara simultan dan terintegrasi antara parameter parameter yang kualitatif atau bahkan yang 'intangible' dan yang kuantitatif (Roy, B., M. Paruccini, 1994). AHP Menggunakan struktur hierarki, matriks, dan algebra linier dalam memformulasikan prosedur pengambilan keputusan. Disamping itu, AHP juga menggunakan prinsip-prinsip eigenvector dan eigenvalue dalam proses pembobotan (saaty, 1990). Menurut Saaty (1993), hirarki didefinisikan sebagai suatu representasi dari sebuah permasalahan yang kompleks dalam suatu struktur multi level dimana level pertama adalah tujuan, yang diikuti level faktor, kriteria, sub kriteria, dan seterusnya ke bawah hingga level terakhir dari alternatif. Dengan hirarki, suatu masalah yang kompleks dapat diuraikan ke dalam kelompok-kelompoknya yang kemudian diatur menjadi suatu bentuk hirarki sehingga permasalahan akan tampak lebih terstruktur dan sistematis. (saaty, 2010)

Tahap-tahap atau prosedur AHP (Rochmasari, 2010), meliputi hal-hal sebagai berikut : 
1. Mendefenisikan struktur hierarki masalah

2. Penilaian kriteria dan alternatif dengan melakukan perbandingan berpasangan.

TABEL 2.1. Skala Penilaian Perbandingan Pasangan

\begin{tabular}{|c|c|c|}
\hline $\begin{array}{c}\text { Tingkat } \\
\text { kepentingan }\end{array}$ & Definisi & Keterangan \\
\hline 1 & Kedua elemen sama pentingnya & $\begin{array}{l}\text { Kedua elemen seimbang sa- } \\
\text { ma besar pada sifat tersebut }\end{array}$ \\
\hline 3 & $\begin{array}{c}\text { Elemen yang satu sedikit lebih } \\
\text { penting daripada elemen } \\
\text { lainnya }\end{array}$ & $\begin{array}{l}\text { Pengalaman menyatakan } \\
\text { sedikit memihak pada satu } \\
\text { elemen }\end{array}$ \\
\hline 5 & $\begin{array}{l}\text { Elemen yang satu lebih penting } \\
\text { daripada elemen lainnya }\end{array}$ & $\begin{array}{c}\text { Pengalaman menunjukkan } \\
\text { secara kuat memihak pada } \\
\text { satu elemen }\end{array}$ \\
\hline 7 & $\begin{array}{c}\text { Satu elemen jelas lebih mutlak } \\
\text { penting daripada elemen } \\
\text { lainnya }\end{array}$ & $\begin{array}{l}\text { Pengalaman menunjukkan } \\
\text { secara kuat disukai dan } \\
\text { didominasi satu elemen yang } \\
\text { sangat jelas lebih penting }\end{array}$ \\
\hline 9 & $\begin{array}{l}\text { Satu elemen mutlak penting } \\
\text { daripada elemen lainnya }\end{array}$ & $\begin{array}{c}\text { Pengalaman menunjukkan } \\
\text { satu elemen sangat jelas } \\
\text { lebih penting }\end{array}$ \\
\hline $2,4,6,8$ & $\begin{array}{c}\text { Nilai tengah diantara dua } \\
\text { penilaian yang berdampingan }\end{array}$ & $\begin{array}{l}\text { Nilai ini diberikan jika } \\
\text { diperlukan kompromi }\end{array}$ \\
\hline & Kebalikan & $\begin{array}{c}\text { Bila elemen ke-ij pada faktor } \\
\text { i mendapat nilai nilai x maka } \\
\text { elemen ke-ji pada faktor ke-j } \\
\text { mendapat nilai } 1 / x\end{array}$ \\
\hline
\end{tabular}

Membuat matriks berpasangan criteria, Tabel 1. Skala Penilaian Perbandingan BerpasanganMembuat matriks berpasangan kriteria terhadap kriteria

1. Menjumlahkan matrik kolom

2. Menghitung nilai elemen kolom kriteria dengan cara membagi setiap nilai elemen kolom dengan jumlah matrik kolom

3. Menentukan prioritas kriteria jumlah baris (n kriteria)

4. Menghitung prioritas alternatif dengan membuat matrik berpasangan alternatif terhadap alternatif sebanyak jumlah kriteria. 
5. Hitung konsistensi

$$
\frac{(\mathrm{Y} / \mathrm{X})}{\mathrm{n}}
$$

Keterangan :

$\mathrm{Y}=$ perkalian antara matriks perbandingan dengan bobot

$\mathrm{X}=$ hasil matriks perbandingan normalisasi

$\mathrm{n}=$ jumlah baris $/$ attribut

6. Konsisensi Indeks (CI)

$$
\mathrm{CI}=\frac{\lambda_{\text {maks }}-\mathrm{n}}{\mathrm{n}-1}
$$

$$
\begin{aligned}
& \text { Keterangan : } \\
& \begin{array}{l}
\lambda_{\text {maks }}=\text { nilai konsistensi } \\
n \quad=\text { jumlah baris }
\end{array}
\end{aligned}
$$

7. Consistency Ratio ( CR ), merupakan pernyataan yang menyatakan seberapa besar derajat Inconsistency dari penetapan nilai perbandingan antar kriteria yang telah dibuat, yaitu :

$$
\mathrm{CR}=\mathrm{CI} / \mathrm{RI}
$$

Keterangan :

$\mathrm{CR}=$ Consistency Ratio

$\mathrm{CI}=$ Consistency Index

$\mathrm{RI}=$ Index Random

TABEL 2.2. Daftar Random Index (RI)

\begin{tabular}{|l|l|}
\hline Ukuran Matriks & Nilai RI \\
\hline 1,2 & 0,00 \\
\hline 3 & 0,58 \\
\hline 4 & 0,90 \\
\hline 5 & 1,12 \\
\hline 6 & 1,24 \\
\hline 7 & 1,32 \\
\hline 8 & 1,41 \\
\hline 9 & 1,45 \\
\hline 10 & 1,49 \\
\hline 11 & 1,51 \\
\hline 12 & 1,58 \\
\hline
\end{tabular}


Apabila nilai $\mathrm{CR} \leq 0,10$ maka data konsisten / dapat ditoleransi tetapi bila $\mathrm{CR} \geq$ 0,10 maka data tidak konsisten dan perlu dilakukan revisi. Apabila nilai $\mathrm{CR}=0$, dapat dikatakan "Perfectly Consistent".

\section{METODE PENELITIAN}

\subsection{Teknik Pengumpulan Data}

Dalam penelitian ini digunakan teknik pengumpulan data yang dilakukan dengan beberapa tahap, diantaranya :

1. Observasi, yaitu melihat dan mengamati secara langsung proses pengolahan data yang ada.

2. Wawancara, yaitu mengumpulkan data yang dilakukan dengan cara melakukan tanya jawab secara langsung kepada pihak-pihak yang terkait guna mendapatkan keterangan-keterangan yang diperlukan.

3. Studi pustaka, yaitu membaca buku-buku atau mencari referensi dari internet yang terkait secara langsung maupun tidak langsung untuk mengetahui secara teoritis permasalahan yang sedang dihadapi.

\subsection{Metode Pengembangan Perangkat Lunak}

Metode Pengembangan Sistem yaitu SDLC (System Development Life Cycle) atau Waterfall merupakan suatu bentuk yang digunakan untuk menggambarkan tahapan dan langkah-langkah didalam tahapan tersebut dalam proses pengembangannya. Tahapan tersebut terdiri dari:

1. System Engineering, merupakan bagian awal dari pengerjaan suatu proyek perangkat lunak. Dimulai dengan mempersiapkan segala hal yang diperlukan dalam pelaksanaan proyek.

2. Analysis, merupakan tahapan dimana System Engineering menganalisis segala hal yang ada pada pembuatan proyek atau pengembangan perangkat lunak yang bertujuan untuk memahami sistem yang ada, mengidentifikasi masalah dan mencari solusinya.

3. Design, tahapan ini merupakan tahap penerjemah dari keperluan atau data yang telah dianalisis ke dalam bentuk yang mudah dimengerti oleh pemakai (user).

4. Coding, yaitu menerjemahkan data yang dirancang ke dalam bahasa pemrograman yang telah ditentukan. 
5. Testing, merupakan uji coba terhadap sistem atau program setelah selesai dibuat.

6. Maintenance, yaitu penerapan sistem secara keseluruhan disertai pemeliharaan jika terjadi perubahan struktur, baik dari segi software maupun hardware.

\section{HASIL DAN PEMBAHASAN}

\subsection{Analisis Kebutuhan Metode AHP}

\subsubsection{Menentukan Kriteria}

Dalam metode AHP terdapat kriteria yang dibutuhkan untuk proses perhitungan nantinya. Dalam kasus ini ada sembilan kriteria yang akan digunakan untuk proses pengambilan keputusan menentukan jurusan. Kriteria-kriteria tersebut adalah :

1. mutlak sangat penting

2. mendekati mutlak dari

3. sangat penting dari

4. mendekati sangat penting dari

5. lebih penting dari

6. mendekati lebih penting dari

7. sedikit lebih penting dari

8. mendekati sedikit lebih penting dari

9. sama penting dengan

\subsubsection{Menentukan Bobot Kriteria Dan Alternatif}

Rating kecocokan setiap alternative penilaian pada setiap kriteria yaitu berupa nilai dari 1 sampai dengan 9. Untuk lebih jelasnya bisa dilihat dari tabel preferensi tiap kriteria pada tabel 4.1 .

TABEL 4.1. Tabel preferensi Bobot untuk kriteria dan alternatif

\begin{tabular}{|c|c|}
\hline Keterangan bobot & Bobot \\
\hline mutlak sangat penting & 9 \\
\hline mendekati mutlak dari & 8 \\
\hline sangat penting dari & 7 \\
\hline mendekati sangat penting dari & 6 \\
\hline lebih penting dari & 5 \\
\hline mendekati lebih penting dari & 4 \\
\hline sedikit lebih penting dari & 3 \\
\hline mendekati sedikit lebih penting dari & 2 \\
\hline sama penting dengan & 1 \\
\hline
\end{tabular}




\subsubsection{Menentukan Bobot Pemilihan Jurusan}

Dikarenakan jurusan yang akan diperoleh dalam proses pemilihan jurusan maka dibutuhkan penilaian atau bobot preferensi yaitu :

TABEL 4.2. Tabel preferensi tiap jurusan

\begin{tabular}{|c|c|}
\hline Keterangan bobot & Bobot \\
\hline mutlak sangat penting & 9 \\
\hline mendekati mutlak dari & 8 \\
\hline sangat penting dari & 7 \\
\hline mendekati sangat penting dari & 6 \\
\hline lebih penting dari & 5 \\
\hline mendekati lebih penting dari & 4 \\
\hline sedikit lebih penting dari & 3 \\
\hline mendekati sedikit lebih penting dari & 2 \\
\hline sama penting dengan & 1 \\
\hline
\end{tabular}

Dari tabel 4.2 di atas, maka selamjutnya menentukan kriteria.

TABEL 4.3. Tabel kriteria

\begin{tabular}{|c|c|}
\hline ID Kriteria & Kriteria \\
\hline C1 & Harga \\
\hline C2 & Prospek \\
\hline C3 & Keinginan \\
\hline
\end{tabular}

Dari tabel 4.3 di atas, selanjutnya menentukan jurusan.

TABEL 4.4. Tabel Jurusan

\begin{tabular}{|c|c|}
\hline ID Jurusan & Jurusan \\
\hline A1 & Sistem Informasi \\
\hline A2 & Teknik Informatika \\
\hline A3 & Manajemen Informatika \\
\hline
\end{tabular}

Analisis Kriteria

TABEL 4.5. Tabel Jurusan

\begin{tabular}{|c|c|c|}
\hline Kriteria Pertama & Penilaian & Kriteria Kedua \\
\hline Harga & 3 & Prospek \\
\hline Harga & 5 & Keinginan \\
\hline Prospek & 1 & Keinginan \\
\hline
\end{tabular}

Setelah membuat tabel 4.4 dan 4.5 maka selanjutnya melakukan penilaian preferensi bobot tiap kriteria pada tiap jurusan seperti pada tabel berikut ini: 
TABEL 4.6. Tabel preferensi bobot kriteria

\begin{tabular}{|c|c|c|c|c|}
\hline Perbandingan & Harga & Prospek & Keinginan & Bobot \\
\hline Harga & 0.652 & 0.600 & 0.714 & $\mathbf{0 . 6 5 5}$ \\
\hline Prospek & 0.217 & 0.200 & 0.143 & $\mathbf{0 . 1 8 7}$ \\
\hline Keinginan & 0.130 & 0.200 & 0.143 & $\mathbf{0 . 1 5 8}$ \\
\hline Jumlah & $\mathbf{1 . 0 0 0}$ & $\mathbf{1 . 0 0 0}$ & $\mathbf{1 . 0 0 0}$ & $\mathbf{1 . 0 0 0}$ \\
\hline
\end{tabular}

Jika konsistensi rasionya sudah terpenuhi selanjutnya melakukan analisis alternatif jurusan. Pertama melakukan analisis alternatif berdasarkan harga.

TABEL 4.7. Tabel penilaian alternatif jurusan

\begin{tabular}{|c|c|c|}
\hline Kriteria Pertama & Penilaian & Kriteria Kedua \\
\hline Sistem informasi & 9 & Teknik informatika \\
\hline Sistem informasi & 5 & Manajemen informatika \\
\hline Teknik informatika & 3 & Manajemen informatika \\
\hline
\end{tabular}

Setelah melakukan penilaian alternatif jurusan berdasarkan kriteria harga maka didapat bobot seperti dibawah ini:

TABEL 4.8. Tabel preferensi bobot alternatif kriteria harga

\begin{tabular}{|c|c|c|c|c|}
\hline Perbandingan & Harga & Prospek & Keinginan & Bobot \\
\hline Sistem informasi & 0.763 & 0.871 & 0.556 & $\mathbf{0 . 7 3 0}$ \\
\hline Teknik informatika & 0.085 & 0.097 & 0.333 & $\mathbf{0 . 1 7 2}$ \\
\hline Manajemen informatika & 0.153 & 0.032 & 0.111 & $\mathbf{0 . 9 9}$ \\
\hline Jumlah & $\mathbf{1 . 0 0 0}$ & $\mathbf{1 . 0 0 0}$ & $\mathbf{1 . 0 0 0}$ & $\mathbf{1 . 0 0 0}$ \\
\hline
\end{tabular}

Selanjutnya melakukan penilaian lainnya berdasarkan kriteria selanjutnya yaitu prospek.

TABEL 4.9. Tabel penilaian alternatif jurusan berdasarkan kriteria prospek

\begin{tabular}{|c|c|c|}
\hline Kriteria Pertama & Penilaian & Kriteria Kedua \\
\hline Sistem informasi & 4 & Teknik informatika \\
\hline Sistem informasi & 8 & Manajemen informatika \\
\hline Teknik informatika & 5 & Manajemen informatika \\
\hline
\end{tabular}

Setelah melakukan penilaian alternatif jurusan berdasarkan kriteria prospek maka didapat bobot seperti dibawah ini: 
TABEL 4.10. Tabel preferensi bobot alternatif kriteria prospek

\begin{tabular}{|c|c|c|c|c|}
\hline Perbandingan & Harga & Prospek & Keinginan & Bobot \\
\hline Sistem informasi & 0.727 & 0.750 & 0.667 & $\mathbf{0 . 7 1 5}$ \\
\hline Teknik informatika & 0.182 & 0.188 & 0.250 & $\mathbf{0 . 2 0 6}$ \\
\hline Manajemen informatika & 0.091 & 0.062 & 0.083 & $\mathbf{0 . 7 9}$ \\
\hline Jumlah & $\mathbf{1 . 0 0 0}$ & $\mathbf{1 . 0 0 0}$ & $\mathbf{1 . 0 0 0}$ & $\mathbf{1 . 0 0 0}$ \\
\hline
\end{tabular}

Selanjutnya melakukan penilaian lainnya berdasarkan kriteria selanjutnya yaitu keinginan.

TABEL 4.11. Tabel penilaian alternatif jurusan berdasarkan kriteria keinginan

\begin{tabular}{|c|c|c|}
\hline Kriteria Pertama & Penilaian & Kriteria Kedua \\
\hline Sistem informasi & 6 & Teknik informatika \\
\hline Sistem informasi & 7 & Manajemen informatika \\
\hline Teknik informatika & 1 & Manajemen informatika \\
\hline
\end{tabular}

Setelah melakukan penilaian alternatif jurusan berdasarkan kriteria keinginan maka didapat bobot seperti dibawah ini:

TABEL 4.12. Tabel preferensi bobot alternatif kriteria keinginan

\begin{tabular}{|c|c|c|c|c|}
\hline Perbandingan & Harga & Prospek & Keinginan & Bobot \\
\hline Sistem informasi & 0.745 & 0.714 & 0.778 & $\mathbf{0 . 7 4 6}$ \\
\hline Teknik informatika & 0.149 & 0.143 & 0.111 & $\mathbf{0 . 1 3 4}$ \\
\hline Manajemen informatika & 0.106 & 0.143 & 0.111 & $\mathbf{0 . 1 2 0}$ \\
\hline Jumlah & $\mathbf{1 . 0 0 0}$ & $\mathbf{1 . 0 0 0}$ & $\mathbf{1 . 0 0 0}$ & $\mathbf{1 . 0 0 0}$ \\
\hline
\end{tabular}

Setelah melakukan analisis alternatif maka didapat tabel data, hasil perangkingan dan hasil perangkingan setelah di urutkan seperti dibawah ini :

TABEL 4.13. Tabel Data Rangking

\begin{tabular}{|l|l|l|l|}
\hline \multirow{2}{*}{\multicolumn{1}{|c|}{ Alternatif }} & \multicolumn{3}{c|}{ Kriteria } \\
\cline { 2 - 4 } & Harga & Prospek & Keinginan \\
\hline Sistem Informasi & 0.72 & 0.71 & 0.74 \\
\hline Teknik Informatika & 0.17 & 0.20 & 0.13 \\
\hline Manajemen Informatika & 0.098 & 0.078 & 0.12 \\
\hline Bobot & 0.65 & 0.18 & 0.15 \\
\hline Jumlah & 1.00000 & 1.00000 & 1.00000 \\
\hline
\end{tabular}


TABEL 4.14. Tabel Hasil Perangkingan

\begin{tabular}{|l|l|l|l|l|}
\hline \multirow{2}{*}{ Alternatif } & \multicolumn{3}{c|}{ Kriteria } & \multirow{2}{*}{ Hasil } \\
\cline { 2 - 5 } & Harga & Prospek & Keinginan & \\
\hline Sistem Informasi & 0.47 & 0.13 & 0.11 & 0.72 \\
\hline Teknik Informatika & 0.11 & 0.038 & 0.021 & 0.17 \\
\hline Manajemen Informatika & 0.064 & 0.014 & 0.018 & 0.098 \\
\hline Ju mlah & 1.00000 & 1.00000 & 1.00000 & 1.00000 \\
\hline
\end{tabular}

TABEL 4.15. Tabel Hasil Perangkingan Setelah di urutkan

\begin{tabular}{|c|l|l|}
\hline \multicolumn{1}{|c|}{ Urutan } & \multicolumn{1}{c|}{ Jurusan } & \multicolumn{1}{c|}{ Hasil Akhir } \\
\hline Hasil Terbaik 1 & Sistem Informasi & 0.72942381265458 \\
\hline Hasil Terbaik 2 & teknik informatika & 0.172233518708022 \\
\hline Hasil Terbaik 3 & $\begin{array}{l}\text { Manajemen } \\
\text { Informatika }\end{array}$ & 0.0983426686374 \\
\hline
\end{tabular}

\subsection{Analisis Permasalahan}

Analisis masalah merupakan langkah awal dari analisis sistem. Langkah ini diperlukan untuk mengetahui masalah apa saja yang terjadi pada sistem yang sedang berjalan. Oleh karena itu langkah pertama adalah menganalisa masalah yang muncul. Ada beberapa masalah yang dihadapi dalam sistem yang sedang berjalan saat ini yaitu:

1. Calon mahasiswa banyak yang masih kesulitan dalam menentukan jurusan.

2. Proses penentuan jurusan masih menggunakan manual, belum terkomputerisasi.

\subsection{Perancangan Sistem}

\subsubsection{Perancangan Antarmuka (Imterface)}

Program aplikasi sistem pendukung keputusan pemilihan jurusan ini merupakan aplikasi yang berbasis website dengan penyimpanan database pada mysql. Program ini terdiri dari tampilan utama, form input, form login, form penilaian, form hasil dan form perankingan.

\section{Tampilan Utama}

Tampilan utama diatas merupakan frame dari aplikasi sistem pendukung keputusan yang terdiri berupa button login dan registrasi yang mana memiliki sub bagian. Sebagai berikut : 
1. Registrasi : Menginput Nama Lengkap, UserName, Password, dan Ulangi Password. 2. Login : Memasukan UserName dan Password.

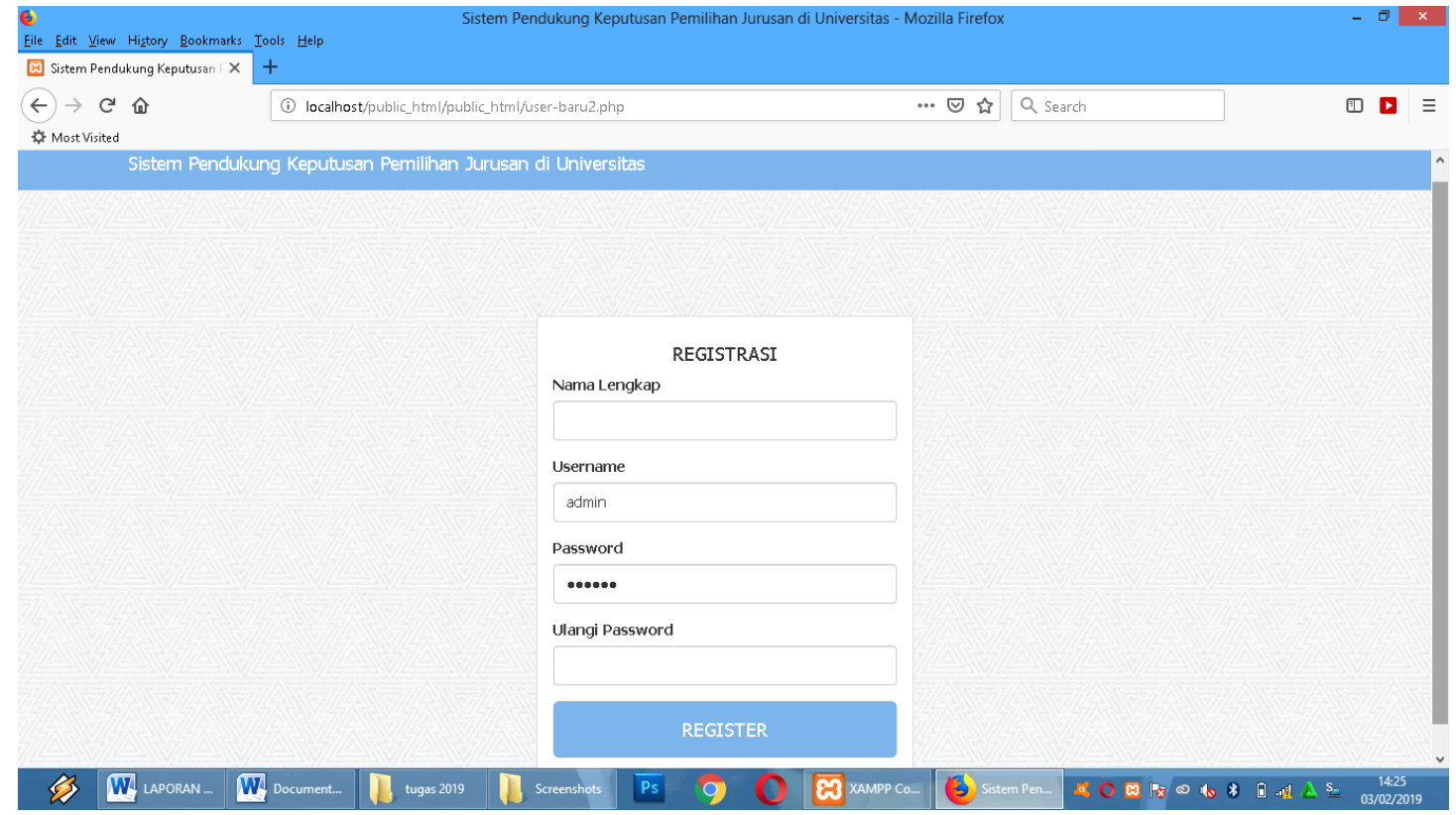

GAMBAR 4.1. Tampilan Utama

\section{Tampilan Login}

Pada tampilam form setelah login terdapat tampilan awal tahap proses sistem berupa pilihan input data (Data Kriteria dna Data alternatif jurusan) dan Analisis Data ( Analisis kriteria, Analisis Alternatip Jurusan, Ranking, dan Laporan).

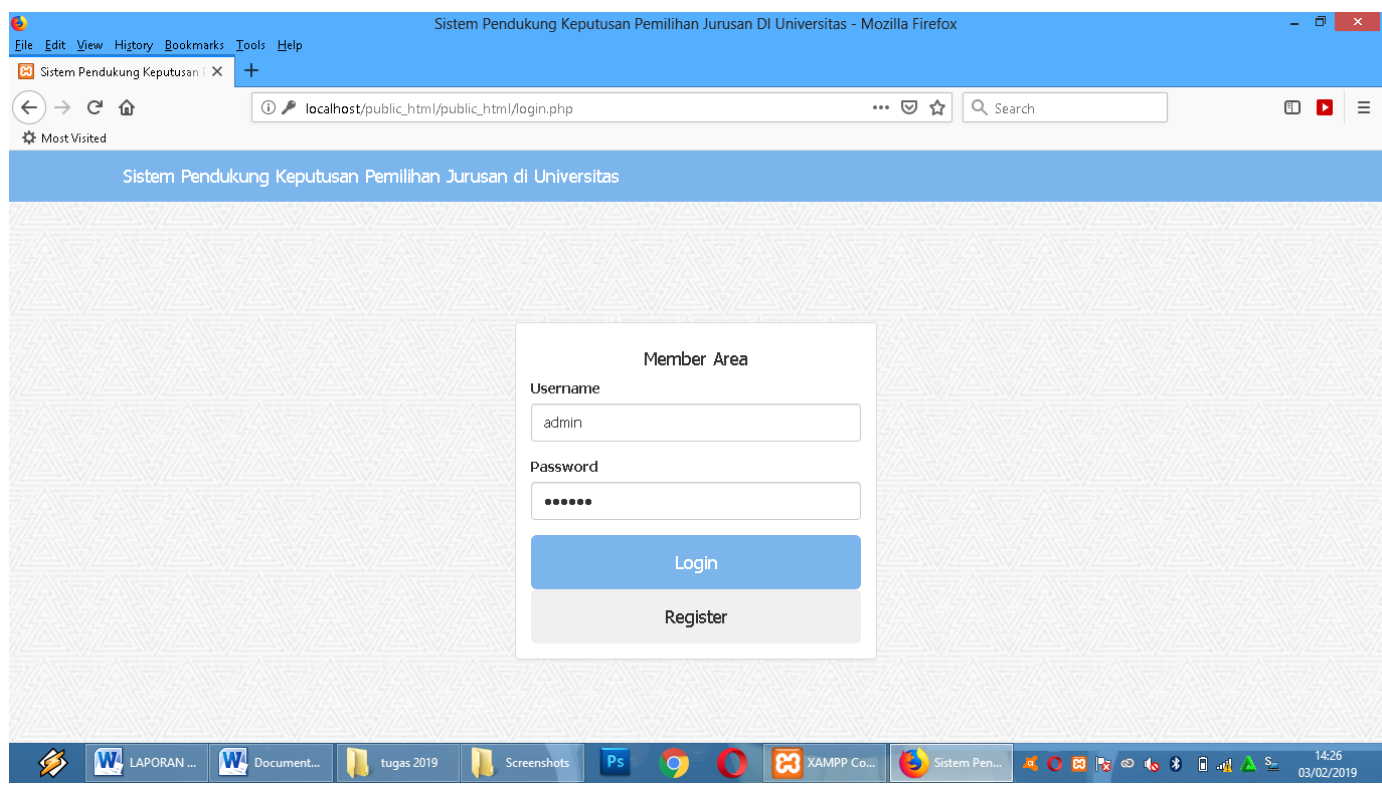

GAMBAR 4.2. Tampilan Login 


\section{Form Awal setelah Login}

Pada form di bawah ini selanjutnya merupakan tahap penginputan berupa Tambah kriteria (ID kriteria contoh : C1,C2,C3..) dan nama kriteria (Nama Jurusan yang akan di ambil).
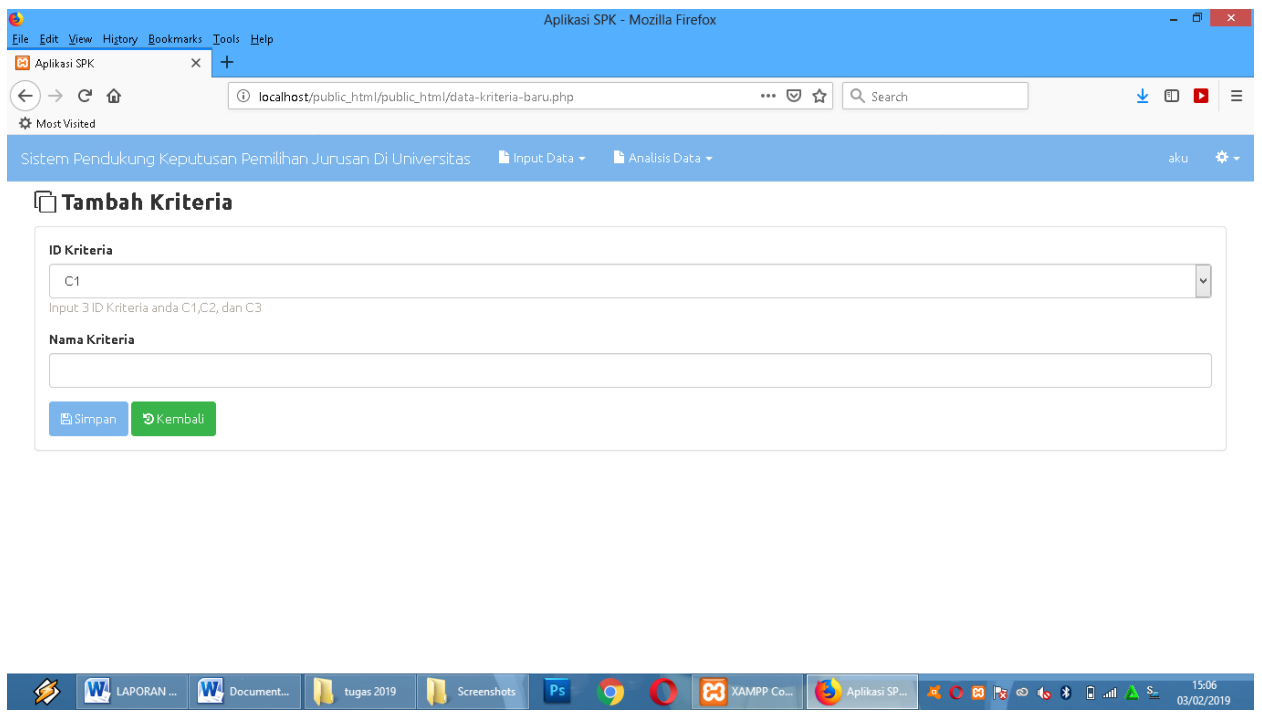

GAMBAR 4.3. Form tambah kriteria

\section{Form Data Kriteria}

Dalam form Data Kriteria ini merupakan form penginputan berupa memasukan ID kriteria (C1,C2.C3), Nama Kriteria ( Harga, Prospek dan keinginan) dan Bobot.

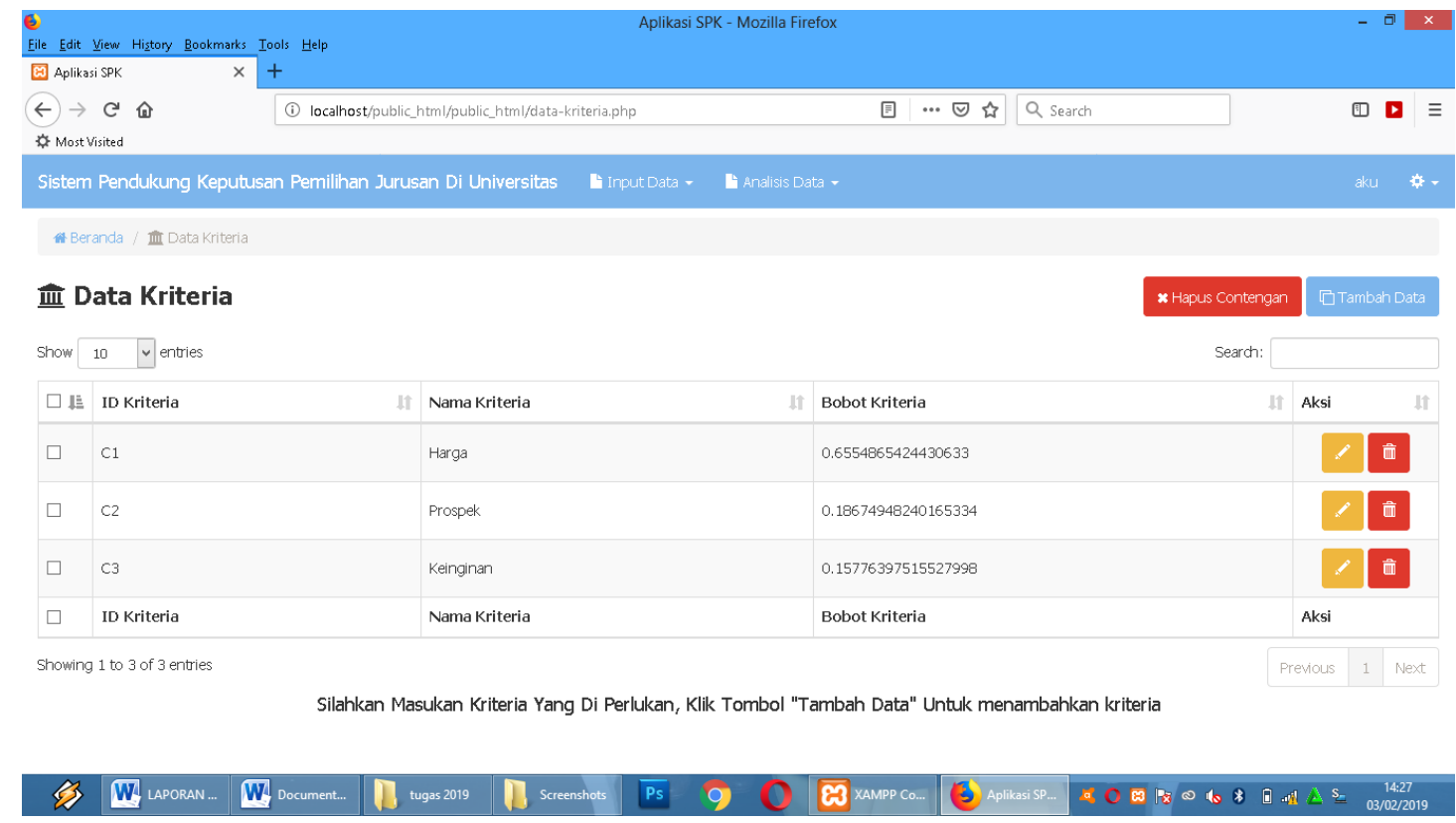

GAMBAR 4.4. Form Data Kriteria 
Selanjutnya merupakan Form Tambah Jurusan berupa ID jurusan dan Nama Jurusan pada pilihan menu Data Alternatif Jurusan.

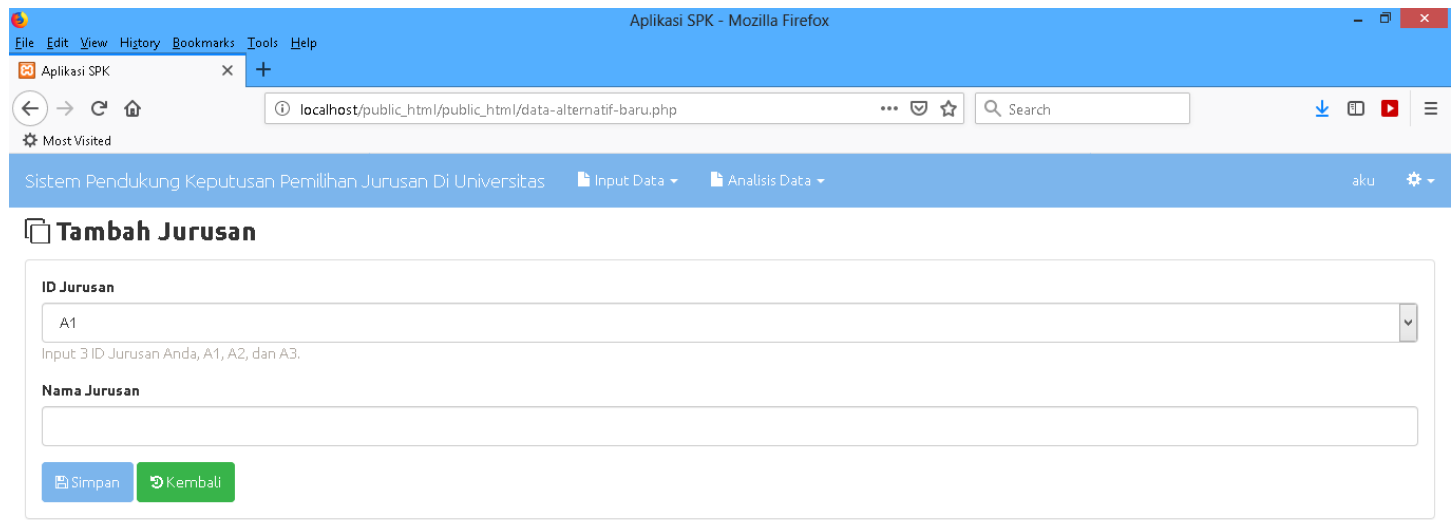

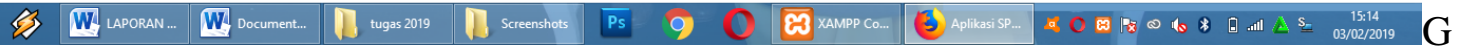

GAMBAR 4.5. Form Tambah Jurusan

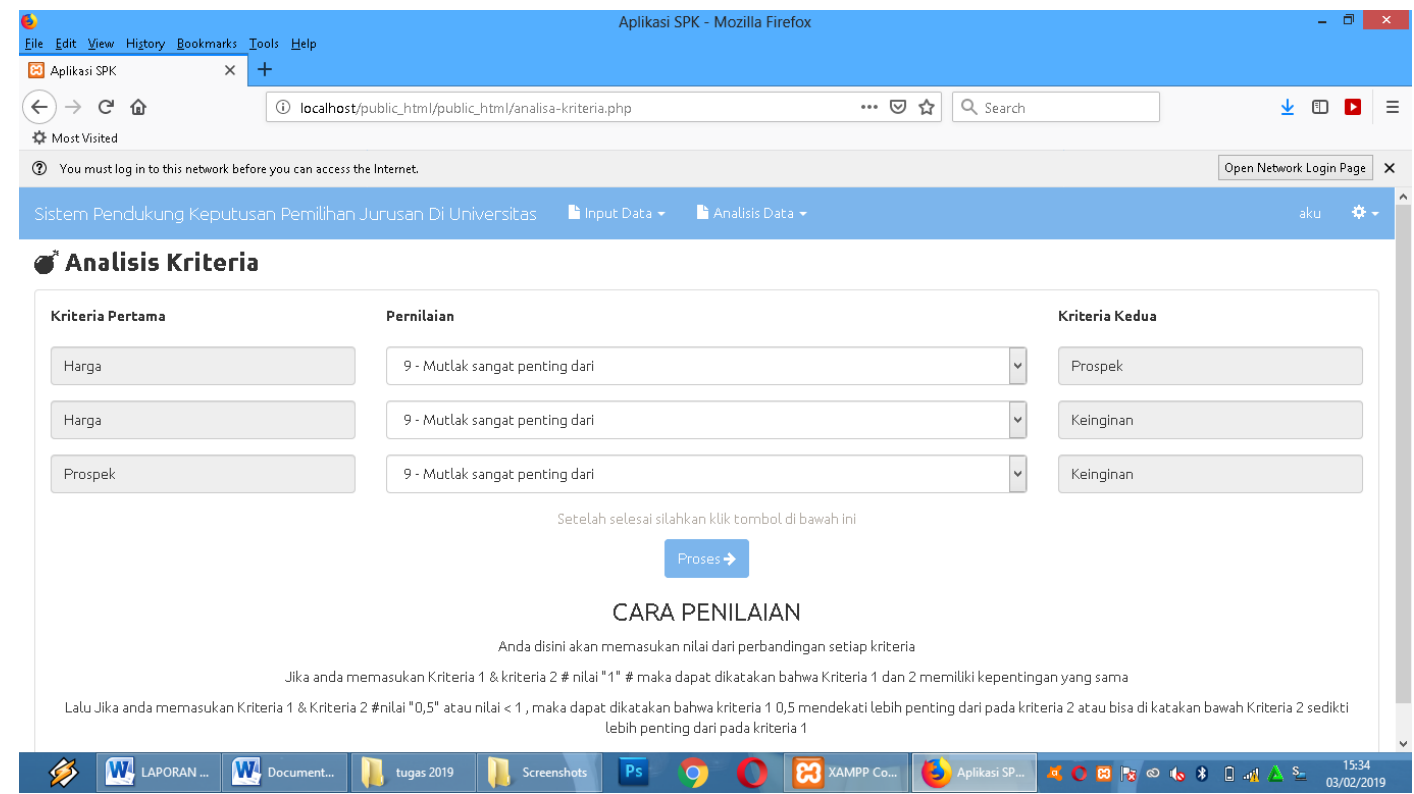

GAMBAR 4.6. Form Analisis Kriteria 
Setelah proses penginputan selesai dimasukan maka hasil proses yang muncul adalah sebagai berikut :

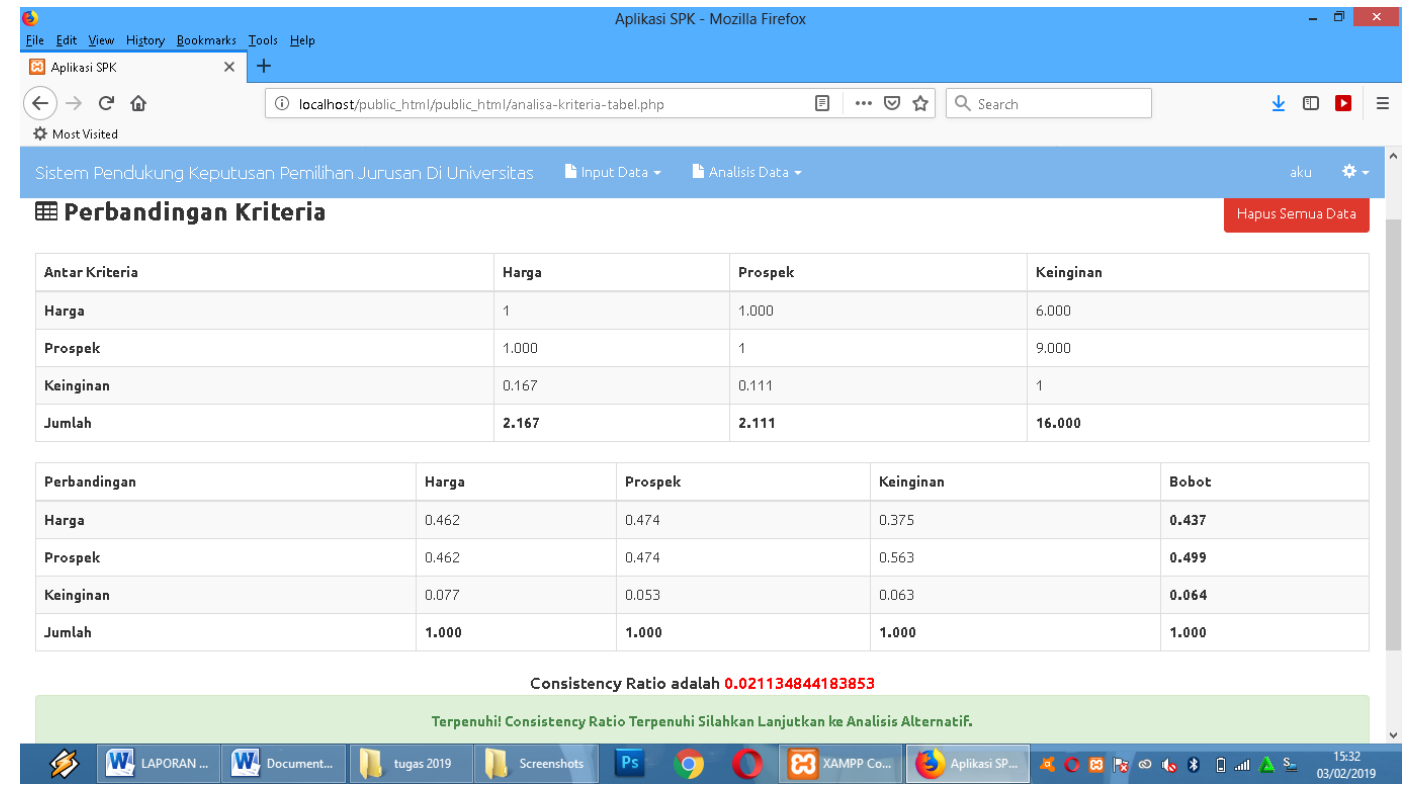

GAMBAR 4.7. Form Perbandingan Kriteria

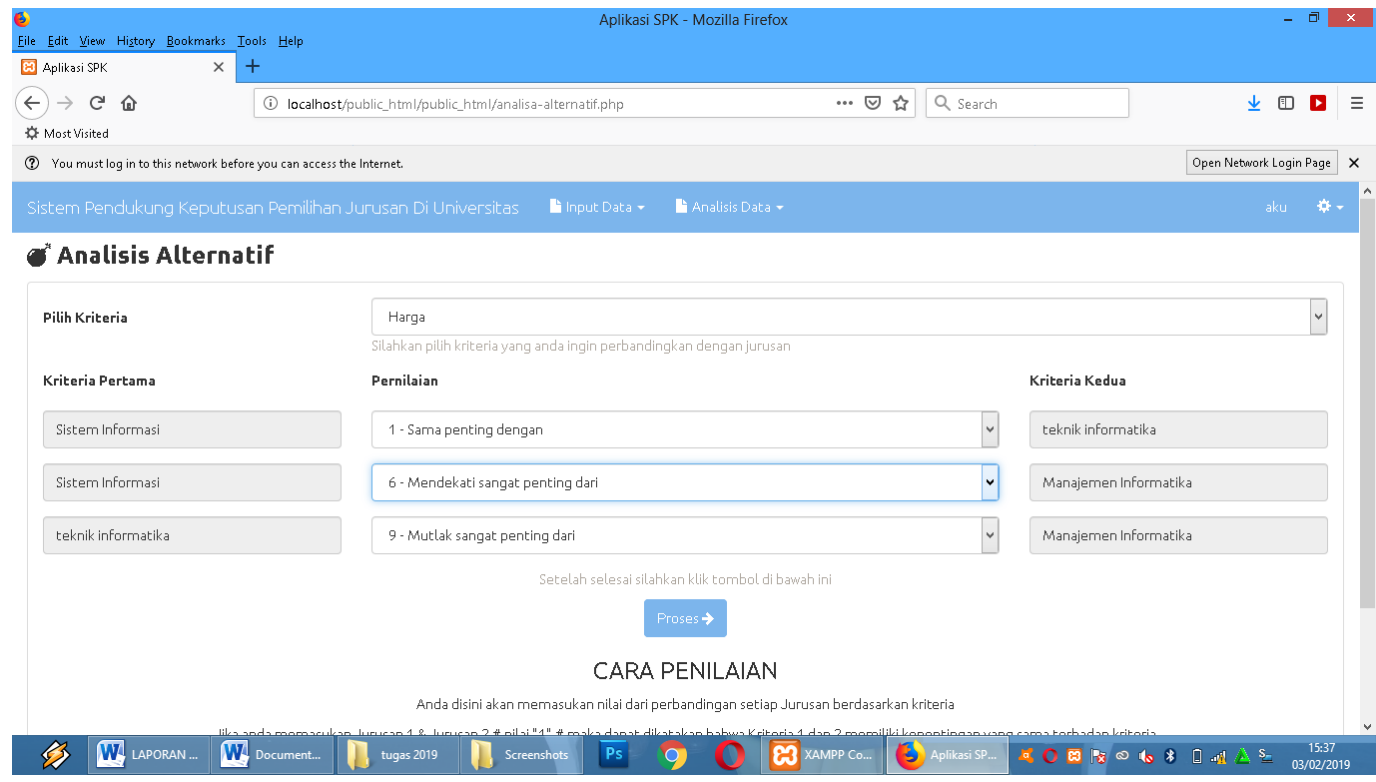

GAMBAR 4.8. Form Analisis Alternatif 


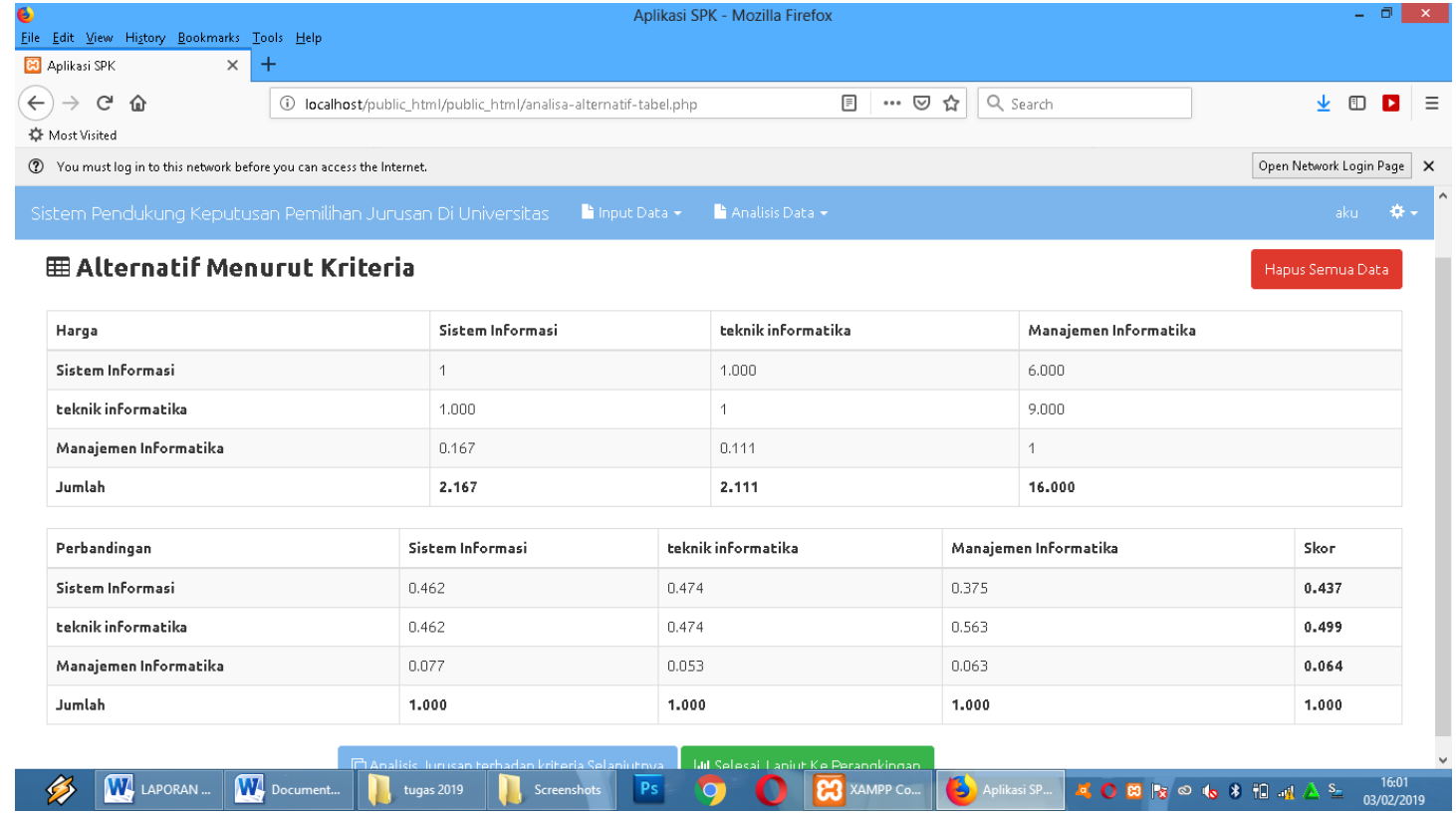

GAMBAR 4.9. Form Alternatif Menurut Kriteria

Form hasil dari proses penilaian yang telah di input berupa nilai rasio paling tinggi dan rendah, hasil perangkingan dan peraangkingan yang telah di urutkan.

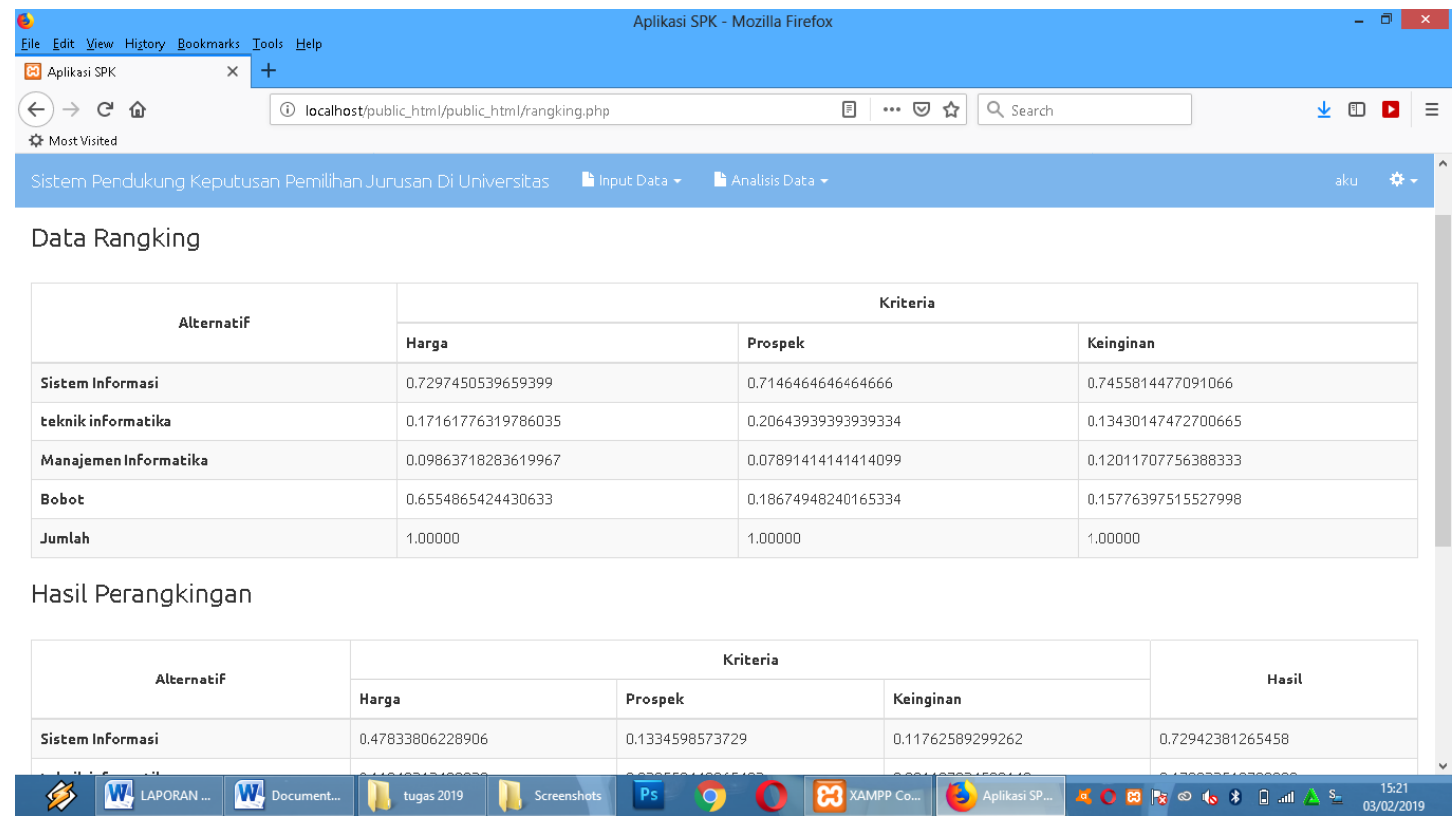

GAMBAR 4.10. Form Data Ranking 


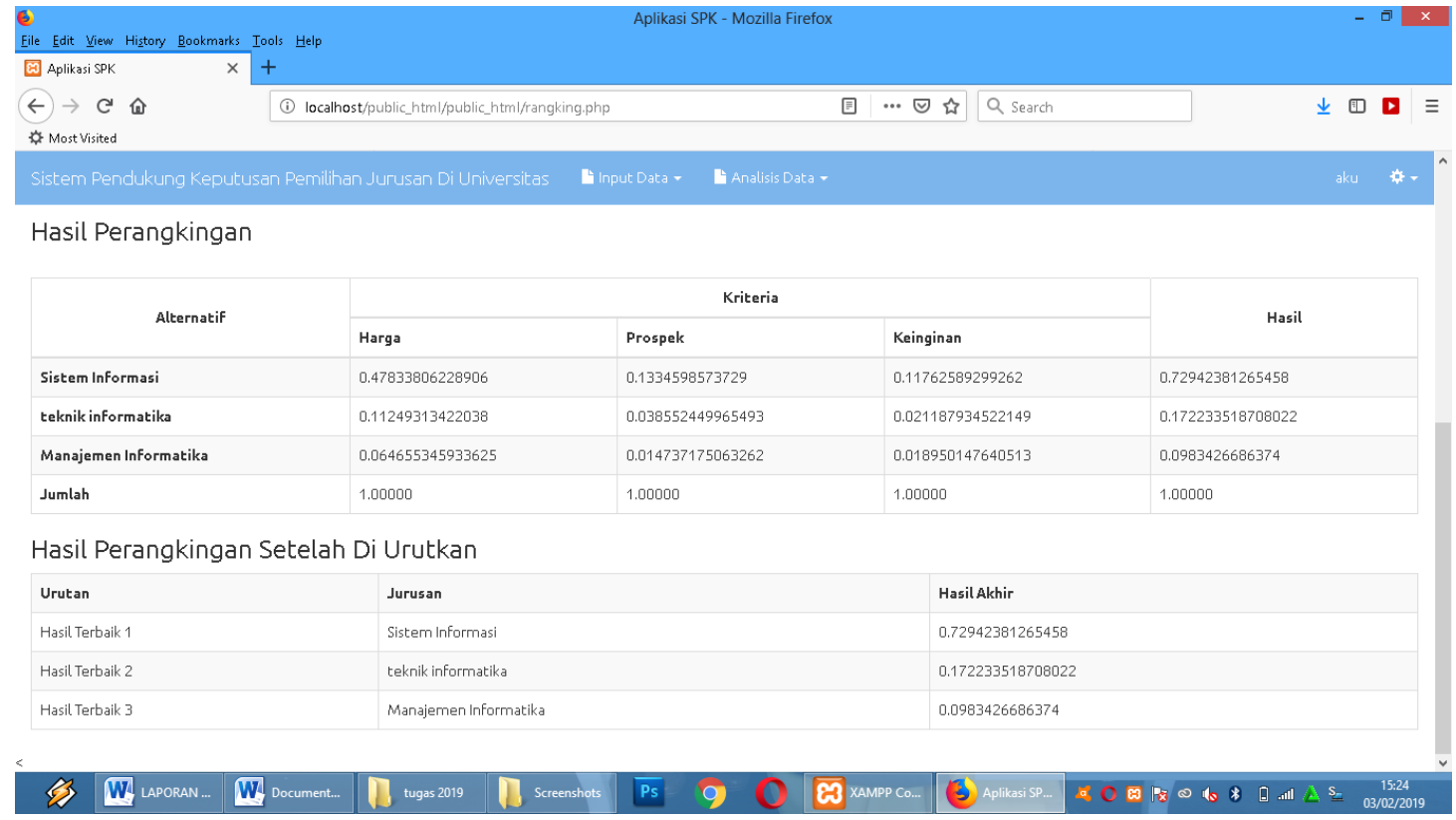

GAMBAR 4.11. Form Hasil Perangkingan

\section{KESIMPULAN}

Kesimpulan dari penelitian ini adalah :

1. Proses pemilihan jurusan di perguruan tinggi mempertimbangkan beberapa hal yaitu biaya dan prospek lulusan.

2. Penerapan metode Analytical Hierarchy Process dalam proses memilih jurusan di perguruan tinggi dan melakukan proses penilaian berdasarkan kriteria-kriteria yang telah ditentukan.

3. Aplikasi sistem pendukung keputusan memilih jurusan di perguruan tinggi menggunakan bahasa pemrograman berbasis PHP, membuat database sebagai media penyimpanan data yang diproses dan membuat output berupa hasil perangkingan.

4. Dengan adanya sistem pendukung keputusan memilih jurusan di perguruan tinggi ini memberikan jawaban yang cepat dalam memilih jurusan yang tepat.

\section{DAFTAR PUSTAKA}

Abdul Kadir, dalam Sistem Informasi, Bandung: Gudang ilmu, 2014, hal.61.

Al-Bahra Bin Ladjamudin, dalam Konsep Diagram Alir Dokumen, jakarta: 2005, hal.72-73. 
Arief, dalam Pemrograman Web, Bandung: Informatika, 2011, hal 7-8.

Asropudin, Pipin, dalam Teknologi Informasi Komunikasi, Bandung: Titian ilmu, 2013, hal.22.

Azhar Susanto, dalam Kumpulan Materi Sistem, yogyakarta: 2013, hal.22.

Dicky Nofriansyah, dalam Konsep Data Mining dan Definisi Sistem Pendukung Keputusan, Bandung: 2014, hal.11.

Dicky Nofriansyah, Sarjon Defit, dalam Multi Criteria Decision Making (MCDM) pada Sistem Pendukung Keputusan, Bandung: 2017, hal.2.

Hidayatullah, Kawistara, dalam pembahasan Basis Data MySQL, jakarta:

2014, hal.147.

Kadir, dalam Definisi Informasi, jakarta: 2013, hal.45.

Kusrini, dalam Sistem Pendukung Keputusan, Jakarta: Informatika, 2007, hal.9.

Lubis, dalam Entity Relationship Diagram (ERD), Jakarta: 2016, hal.31.

M.F Mundzir, dalam PHP Tutorial Book for Beginner, Edisi ke Satu, Jakarta: Notebook, 2014, hal. 7-38.

Nugroho, dalam pengertian MySQL, Edisi ke satu, jakarta: 2013, hal.26.

Nur Elfi, Yvonne Wangdra, dalam Rekayasa Perangkat Lunak, Jakarta: Ilmu Teknologi, 2016, hal.119.

Romney, Steinbert, dalam Analisis dan Desain Sistem Informasi, jakarta: Library binus, 2015, hal.3.

Rosa, Salahuddin, dalam Rekayasa Perangkat Lunak: Terstruktur dan Berorientasi Objek, Edisi ke Dua, Bandung: Informatika, 2014, ha.28-67.

Sutarman, dalam Pengantar Teknologi Informasi, jakarta: Bumi Aksara, 2012, hal.3-14.

Turban, dalam Konsep dan Aplikasi Sistem Pendukung Keputusan, Edisi ke satu, Yogyakarta:, 2005, hal.321.

Winarno, Edy dan Zak, dalam Desaign Web Responsif Dengan Html 5 \& CSS3, Elek Media Komputerindo, Jakarta: 2015.

Saefudin, Sri Wahyuningsih, 2014, Sistem pendukung Keputusan Untuk Penilaian Kinerja Pegawai Menggunakan Metode Metode Analytical Hierarchy Process (AHP) Pada RSUD Serang, Jurnal Sistem Informasi. Vol 1 No. 12014 